\title{
Determinants of foreign direct investment in ASEAN: A panel approach
}

\author{
Hong Hiep Hoang* and Duc Hung Bui
}

Institute of Social Sciences of the central Region (ISSCR), Vietnam Academy of Social Sciences; No. 18, Khai Tay 2, Hoa Quy Street, Ngu Hanh Son District, Da Nang City, Viet Nam

\begin{tabular}{l}
\hline C H R O N I C L E \\
\hline Article history: \\
Received September 18, 2014 \\
Accepted 21 December 2014 \\
Available online \\
December 272014 \\
\hline Keywords: \\
FDI \\
ASEAN \\
Panel \\
Determinants \\
FGLS
\end{tabular}

\begin{abstract}
A B S T R A C T
This paper analyzes the factors of FDI inflows in ASEAN countries over the period 1991 to 2009. The results indicate that the market size, trade openness, quality infrastructure, human capital, labor productivity are the main factors that have positive impacts on FDI inflows. Additionally, exchange rate policy, real interest rate, political risk and corruption also affect FDI inflows. Surprisingly, the cheap labor does not help to attract FDI to the region, because foreign investors are particularly interested in labor productivity. This study also shows that the Asian financial crisis in 1997 affected the amount of FDI inflows, but not on the nature of FDI inflows in the region.
\end{abstract}

\section{Introduction}

Since the implementation of the ASEAN Investment Agreement (AIA), ASEAN has been committed to strengthen its investment regime. Under the Free Trade Area ASEAN (AFTA) free flow of investment is targeted as a core measure to achieve an integrated single market and production base, along with free movement of goods, services, and free flow of capital. This can help ASEAN countries attract more FDI. In fact, with high economic development achievements in the period 1991-1997, ASEAN has become a red destination for international investors in the choice of investment location. In this period, FDI inflows to ASEAN reached about $8 \%$ of world total FDI. The Asian financial crisis of 1997 ended the golden age of ASEAN in attracting FDI. Asia in general and ASEAN in particular is no longer a "paradise" in the eyes of international investors, international investment patterns have changed dramatically, FDI inflows shifts to developed countries. The success of economic reform and the revival of economic growth after the crisis have boosted FDI flows into ASEAN, FDI in the region rose from 17,3 billion U.S. dollars in 2002 to 92,7 billion U.S. dollars in 2010 (about 7,08\% of world total FDI). ASEAN is an important component of international investment activities. 
However, FDI inflows are unequally distributed among the members of ASEAN. At the end of 2010, the total stock of FDI is mainly concentrated in countries ASEAN6 ${ }^{1}$ with a total value of 945,9 billion U.S. dollars, representing about $97,17 \%$ of total FDI in ASEAN. In particular, Singapore has attracted 461,4 billion U.S. dollars, which represents approximately 47,4\% of the total FDI in ASEAN; Thailand, 14,1\%; Malaysia 10,4\%; Indonesia, 15,8\%; Vietnam, 6,7\%; and Philippines, 2,7\%. The rest is only $2,83 \%$ of total FDI in ASEAN. Therefore, the purpose of this paper is to provide an overview of the determinants of FDI location in the region. The rest of the paper is organized as follows: Section 2 presents the literature review, Section 3 presents the model specification, Section 4 presents the empirical results, and Section 5 concludes.

\section{Literature Review}

There are many theories, which attempt to explain the determinants of FDI. Among them, Dunning and Lundan (2008) proposed a comprehensive theoretical framework relatively of the determinants of FDI. They described four main types of FDI. The first type of FDI is called market-seeking: These are enterprises that invest in a particular country or region to supply goods or services to local and regional markets. Market-seeking investment may be undertaken to sustain or protect existing markets, or to exploit or promote new markets. Together with market size and market growth of the host economy, obstacles to accessing local markets, such as tariffs and transport costs, also encourage this type of FDI. A second type of FDI is called resource-seeking: There are three main types of resource seekers. First, there are those seeking physical resources of one kind or another. The resources they seek include mineral fuels, industrial minerals, metals and agricultural products, etc. The second group of resourceseeking MNEs comprise those seeking plentiful supplies of cheap and well-motivated unskilled or semi-skilled labour. The third type of resource-seeking FDI is prompted by the need of firms to acquire technological capability, management or marketing expertise and organisational skills. The third type of FDI, called efficiency-seeking: Efficiency-seeking FDI is of two main kinds. The first is that designed to take advantage of differences in the availability and relative cost of traditional factor endowments in different countries. The second kind of efficiency-seeking investment is that which takes place in countries with broadly similar economic structures and income levels and is designed to take advantage of the economies of scale and scope, and of differences in consumer tastes and supply capabilities. The fourth type of FDI, called strategic asset-seeking: They usually come by acquiring the assets of foreign corporations, to promote their long-term strategic objectives - especially that of sustaining or advancing their global competitiveness.

In addition, Nachum (1999) also analysed relatively the host country determinants of FDI. They were classified into the three groups. These are politic factors, business facilitation and economic factors. Empirically, Asiedu (2002) analyzed the determinants of FDI to developing countries and examined why sub-Saharan Africa (SSA) was relatively unsuccessful in attracting FDI despite policy reform. Using ordinary least square (OLS) for cross-section regressions and a panel regression, he finds that the factors that drive FDI to developing countries had a different impact on FDI to SSA. Specifically, infrastructure development and a higher return on capital promote FDI to non-SSA countries, but had no significant impact on FDI to SSA. Openness to trade promotes FDI to both SSA and non-SSA countries. However, the marginal benefit from increased openness is less for SSA - suggesting that trade liberalization will generate more FDI to non-SSA countries than SSA countries. Mina (2007) studied the location determinants of FDI flows to the six Gulf Cooperation Council (GCC) countries for the period 1980-2002. Adopting panel data models methodology, he surprisingly reported that oil production, oil reserves, and oil prices could reduce FDI inflows. He also reported that while better institutional quality, trade openness and infrastructure development could increase FDI inflows, human capital significantly reduces them.

There are very few empirical studies of the determinants of FDI flows into ASEAN. Mamadou (2002) analyzed the factors of FDI into ASEAN and Latin America (MERCOSUR) for the period from 1980

\footnotetext{
${ }^{1}$ ASEAN6 includes Singapore, Thailand, Malaysia, Indonesia, Vietnam, and Philippines.
} 
to 1998 . He found that the exchange rate and market size were factors influencing significantly on FDI flows into MERCOSUR. Meanwhile, FDI flows into ASEAN were only affected by the exchange rate. The analysis also explains why foreign capital flows contribute to print for a regional integration process a higher vertical degree in ASEAN than in MERCOSUR. Ismail (2009) used a semi gravity model to identify the determinants of FDI in ASEAN countries covering the period from 1995 to 2003. The dataset covers 18 source countries from various investors in the world and 9 host countries, which include all ASEAN members except Cambodia. The results revealed that besides the market size for host and source country, other criteria such as the shorter the distance, common in language and border, the extended market relative to distance also attracts more foreign investors. Other macroeconomic factors such as lower inflation rate, the slightly higher in exchange rate and good management of the government budget are among the key factors that attract more FDI. In addition to economic factors, social factors such as good telecommunication and infrastructure and non-economic factors such as transparency and trade policy also encourage more investors to the ASEAN. Masron and Abdullah (2010) studied the impact of institutional quality on FDI flows into ASEAN for the period 1996-2008. Adopting panel data models methodology, they found an indication that improving the institutional quality was also crucial as part of future policy strategy to further attract new FDI flows into the region. Besides, they also found positive effects of market size, human capital, and the opening of the economy for FDI flows into ASEAN.

\section{Model Specification}

This study uses a panel of the six ASEAN countries: Vietnam, Indonesia, Malaysia, Philippines, Singapore, and Thailand. For our dependent variable, we take the natural logarithm of 1 plus FDI inflows to each country on the period 1991-2009. The model for this study is specified as:

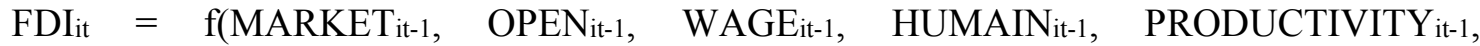

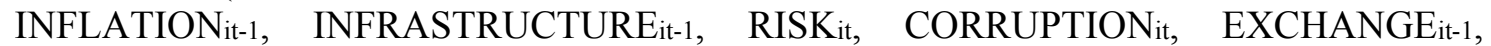

$$
\begin{aligned}
& \text { INTEREST }_{\text {it-1 }}, \text { FINANCE }_{\text {it-1 }} \text { ) }
\end{aligned}
$$

We use $i$ for some countries and $t$ for some time units. Most explanatory variables are taken in original terms one-year lagged from the year of the dependent variable. The use of lagged explanatory variables helps to solve endogeneity problems and relates to a simple hypothesis for the foreign investor decisionmaking. Foreign investor are assumed to make an investment decision for a given year by referring to the observable variables of the previous year for each region (Iwasaki \& Suganuma, 2005; Svetlana, 2009). Market size of the host country (MARKET) reflects the economic conditions and potential demand, it is an important factor affecting the decision of the foreign investors. Foreign investors may be attracted by the size of the market, which could enable them to take advantage of sales in the host country. The importance of the scale of the internal market has been validated by studies of Asiedu (2006), Blonigen et al. (2007), Hattari et al. (2008), Wahid et al. (2009), Poelhekke et Van Der Ploeg (2009), Garretsen et Peeters (2009), Mottaleb and Kalirajan (2010), and Masron and Abdullah (2010). To represent the market size, we use the natural logarithm of gross domestic product (GDP). This variable is used to reflect the potential of the internal market for products of foreign investors, we expect a positive impact on FDI inflows.

The trade openness (OPEN) resenting the opening, the link, the level of economic integration in the host country with the world economy. The opening means that trade barriers for goods the host country have been gradually relaxed. It is an opportunity for foreign investors who can exploit the comparative advantage of host country to re-export to the country of origin as well as increased exports to the rest of the world (vertical FDI). Studies Noorbakhsh et al. (2001), Asiedu (2006), Wahid et al. (2009), Mottaleb and Kalirajan (2010), Masron and Abdullah (2010) confirmed a significantly positive effect of openness to FDI. In this study, trade openness is defined as the sum of exports and imports over GDP. We expect a significantly positive correlation between openness and FDI inflows.

Labor cost (WAGE) is an important factor of production that can directly influence the economic benefit of investors. Foreign investors often take advantage of cheap labor in developing countries to 
minimize production costs. Thus, the low labor cost has an important role to attract FDI (see Friedman et al., 1996; Wahid et al., 2009). However, labor cost also has a close relationship with labor productivity. So, if labor costs present the qualification of labor, FDI flow may to areas that have a higher level of wages due to its high demand for skilled labor. Studies by Wei (2000), Axarloglou (2004), and Hayakawa et Matsuura (2011) confirmed the existence of a positive correlation between labor costs and FDI inflows. In this study, we use the natural logarithm of monthly average wage in the manufacturing sector representing the variable nominal labor costs (WAGE) ${ }^{2}$. In fact, because the wage data in Vietnam is unavailable. So we use the monthly average wage in the state sector which is given by the General Statistics Office of Vietnam to measure the nominal labor costs in Vietnam. The wage data in the manufacturing sector in Malaysia are found on the website of Department of Statistics Malaysia. The wage data in other countries are found on The International Labor Organization. However, the wage data in Philippines are missed in the years 2000, 2002, 2004, 2007. So linear interpolation was used for the years.

Human Capital (HUMAIN) represents the quality of labor in host countries, the qualitative worker can handle quickly and efficiently machines and new technologies, and in general it has a higher labor productivity. Depending on the type and the nature of productive activities (application of technology up or down), the difference between nominal wages and relative wages (through the analysis of labor productivity) that human capital has different effects for investment decision of foreign investors. Noorbakhsh et al. (2001), Masron and Abdullah (2010), Axarloglou (2004), Asiedu (2006), and Wahid et al. (2009), found a significantly positive correlation between human capital and FDI inflows, and capital human plays a key role in attracting FDI into the host country. We use the ratio of skilled labor to numbers of employees as a proxy for human capital. Skilled labor is defined as the total employees in categories (1) professional, technical and related workers, (2) administrative and managerial workers and (3) clerical and related workers.

Labor productivity (PRODUCTIVITY) reflects the efficiency of labor in the economy. Cushman (1987) found that the decline in labor productivity has limited FDI flows from the UK, France, Germany, Canada, and Japan into the United States. Woodward (1992) and Axarloglou (2004), also found a positive relationship between labor productivity and FDI inflows. Labor productivity is measured by the natural logarithm of GDP per employee.

Political stability (RISKS) indicates the level of political risk, institutional quality, and it also partly reflects the investment environment "soft". Wei (2000), Asiedu (2006), Hattari et al. (2008), Wahid et al. (2009), and Masron and Abdullah (2010), Mengistu and Adhikary found a significant positive relationship between FDI inflows and political stability. Ali et al. (2010) also found a significant impact of institutional quality for FDI in manufacturing, and particularly in services. In this study, we use the natural logarithm of general index of political risk from the International Country Risk Guide (ICRG), which is synthesized from 12 different criteria (see ICRG) to represent the variable of political stability. The progress of the overall index reflects the level of political risk becoming smaller, or political stability is progressive. In addition, we also use The Control of Corruption index (ICRG database) to measure the quality of institutions in each country, higher index indicates better control of corruption.

Inflation rate (INFLATION) reflects the macroeconomic instability. The stable macroeconomy may reduce the uncertainty of the investment environment, and increase the level of confidence for the economy. Thus, high inflation could limit FDI inflows. Asiedu (2006), and Kinda (2008) found a significant negative impact of inflation for FDI inflows. In this study, the variable of inflation is measured by the annual percentage change in the index of consumer prices.

Interest rate (INTEREST) reflects the cost of capital when investors want to use the financial resources in the host country, this is the entry costs of production activities and business. A low interest rates may encourage investors to raise capital in the host country to finance their investment activities. Therefore, interest rate is also an important factor for FDI inflows. Culem (1988) found that the difference between

\footnotetext{
${ }^{2}$ All wage data in the countries are converted into U.S. dollars.
} 
the nominal interest rate of the host country and the rest of the world has a significant negative correlation with FDI inflows. Similarly, Beer and Cory (1996) found that the difference in interest rates between the two countries has a negative relationship with FDI flows of U.S. to Europe. Conversely, Çevis and Çamurdan (2007) found a positive correlation between real interest rates and FDI flows to developing countries and economies in transition. Mercereau (2005) also concluded that the low interest rates in the G3 (U.S., Japan, Germany) had a positive impact on FDI flows to Asia. We use the real interest rate for the variable and expect a negative relationship with FDI inflows.

Financial development (FINANCE): The financial development enables companies (mostly private) to approach easily and effectively funding sources with low-cost. It also creates an environment conducive to the exchange and cooperation between companies, including foreign firms with domestic firms. Noorbakhsh et al. (2001) showed a significant positive correlation between financial development and FDI flows to developing countries. Using a panel of 97 countries over the period of 20 years, Dutta and Roy (2008) found a concave relationship between financial development and FDI inflows: before the financial development reaches a certain threshold, financial development has a positive impact on entries FDI, but when he crosses the threshold, financial development has a negative impact on FDI inflows. Asiedu (2002), Kinda (2008), also found a positive correlation between financial development and FDI inflows but not statistically significant. In this study, we use the domestic credit provided by banking sector (\% of GDP) to present the financial development variable. Infrastructure development (INFRASTRUCTURE) increases productivity of investment and is an important factor to attract FDI flows. Asiedu (2002, 2006), Moosa and Cardak (2006), Kinda (2008), Mengistu and Adhikary (2011), found that the quality of infrastructure has a positive effect on FDI inflows. We use total numbers of phones and mobile phone users (per 100 people) to represent the development of infrastructure. We expect a positive correlation between FDI inflows and developing infrastructure.

Exchange rate (EXCHANCE) represents price competition. We expect a positive relationship between FDI inflows and exchange rates, because a higher exchange rate (that is to say that the currency of the host country depreciates against the currency compared) reflects an improvement in competitiveness of exported goods. Klein and Rosengren (1990) found that after controlling for relative wages, a percentage increase in the value of foreign currency (as a percentage of depreciation of U.S. dollar) will have a significant impact on FDI flows to United States. Froot et Stein (1992) also concluded that in general FDI flows to the United States have a significantly negative correlation with the value of U.S. dollar and that a currency devaluation will encourage foreign investors to buy the control productive assets of domestic companies. Mamadou (2002) found a significant positive correlation between exchange rates and FDI flows into ASEAN. We use the natural logarithm of exchange rate of currency of the host country against the U.S. dollar for present exchange rate. Data sources are given in Appendix 1.

\section{Regression Methodology and Results}

This study uses an unbalanced panel of the six ASEAN countries: Vietnam, Indonesia, Malaysia, Philippines, Singapore, and Thailand in the period 1991-2009. Because the number of countries is small $(\mathrm{i}=6)$ and there is a strong correlation between certain variables (such as HUMAIN, OPEN, PRODUCTIVITY, WAGE, INTERACTION), we introduce these variables alternatively in different models. Technically, the panel data may exist group effects, time effects, or both. These effects can be fixed effects or random effects. The Hausman test is performed to find whether the fixed effects model (FEM) or random effects models (REM) is suitable. In addition, we also use the Ramsey-Reset test to verify the characteristics of model. The results showed that the REM model is more appropriate than the model FEM. Then we use the Wald test to test group-wise Heteroscedasticity (Greene, 2000), and the test proposed by Wooldridge (2002) to test the serial correlation (see Table 1). In case all models are group-wise heteroscedasticity and the number of individuals is less than twice the number of time units, the Feasible Generalized Least Squares (FGLS) is the right choice (Beck \& Katz, 1995; Hoechle, 2007). The FGLS regression results are presented in Table 1. The results of the regression REM are presented in Appendix 2. In general, the results of the FGLS regression and REM are similar. However, 
the major difference is that the standard errors of most regressive coefficients are significantly reduced, the probability values reported decrease and the validity of the estimated coefficients increases.

Table 1

Determinants of FDI inflows in ASEAN (1991-2009)

\begin{tabular}{|c|c|c|c|c|c|c|}
\hline $\begin{array}{c}\text { Model } \\
\text { Estimation method } \\
\end{array}$ & $\begin{array}{c}\text { (1) } \\
\text { FGLS }\end{array}$ & $\begin{array}{c}\text { (2) } \\
\text { FGLS }\end{array}$ & $\begin{array}{c}\text { (3) } \\
\text { FGLS }\end{array}$ & $\begin{array}{c}\text { (4) } \\
\text { FGLS }\end{array}$ & $\begin{array}{c}\text { (5) } \\
\text { FGLS }\end{array}$ & $\begin{array}{c}\text { (6) } \\
\text { FGLS }\end{array}$ \\
\hline \multirow[t]{2}{*}{ MARKET } & $0.517 * * *$ & $0.635 * * *$ & $0.359 * * *$ & $0.607 * * *$ & $0.644 * * *$ & $0.402 * * *$ \\
\hline & $(0.114)$ & $(0.121)$ & $(0.115)$ & $(0.119)$ & $(0.0811)$ & $(0.124)$ \\
\hline \multirow{2}{*}{ EXCHANGE } & $0.147 * * *$ & $0.125 * * *$ & $0.199 * * *$ & $0.157 * * *$ & $0.0549 * *$ & \\
\hline & $(0.0328)$ & $(0.0309)$ & $(0.0323)$ & $(0.0310)$ & $(0.0219)$ & \\
\hline \multirow[t]{2}{*}{ INTEREST } & $-0.0332 * * *$ & $-0.0638 * * *$ & $-0.0290 * * *$ & $-0.0281 * *$ & $-0.0290 * * *$ & \\
\hline & $(0.0116)$ & $(0.0180)$ & $(0.0106)$ & $(0.0111)$ & $(0.0103)$ & \\
\hline \multirow[t]{2}{*}{ CORRUPTION } & $0.367 * * *$ & $0.479 * * *$ & $0.324 * * *$ & $0.305 * * *$ & & $0.315 * * *$ \\
\hline & $(0.101)$ & $(0.101)$ & $(0.0934)$ & $(0.103)$ & & $(0.0699)$ \\
\hline \multirow[t]{2}{*}{ WAGE } & $0.609 * * *$ & & & & & \\
\hline & $(0.109)$ & & & & & \\
\hline \multirow[t]{2}{*}{ HUMAIN } & & $0.0290 * * *$ & & & & \\
\hline & & $(0.00539)$ & & & & \\
\hline \multirow[t]{2}{*}{ PRODUCTIVITY } & & & $0.674 * * *$ & & & \\
\hline & & & $(0.0974)$ & & & \\
\hline \multirow[t]{2}{*}{ WAGE*PRODUCTIVITY } & & & & $0.0403 * * *$ & & \\
\hline & & & & $(0.00641)$ & & \\
\hline \multirow[t]{2}{*}{ RISK } & & & & & $2.511 * * *$ & \\
\hline & & & & & $(0.718)$ & \\
\hline \multirow[t]{2}{*}{ OPEN } & & & & & $0.00420 * * *$ & \\
\hline & & & & & $(0.000882)$ & \\
\hline \multirow[t]{2}{*}{ INFLATION } & & & & & & -0.0101 \\
\hline & & & & & & $(0.0190)$ \\
\hline \multirow[t]{2}{*}{ INFRASTRUCTURE } & & & & & & $0.340 * * *$ \\
\hline & & & & & & $(0.0537)$ \\
\hline \multirow[t]{2}{*}{ FINANCE } & & & & & & -0.000910 \\
\hline & & & & & & $(0.00210)$ \\
\hline \multirow[t]{2}{*}{ Constant } & 4.104 & 3.716 & $5.528 * *$ & 3.372 & -5.708 & $10.17 * * *$ \\
\hline & $(2.904)$ & $(3.196)$ & $(2.732)$ & $(3.095)$ & $(4.042)$ & $(3.060)$ \\
\hline Number of Observation & 100 & 94 & 104 & 92 & 106 & 99 \\
\hline Wooldrige Test & 0.35 & 2.06 & 0.00 & 3.46 & 0.08 & 0.00 \\
\hline Modified Wald Test & $45.33 * * *$ & $28.25 * * *$ & $25.42 * * *$ & $23.56 * * *$ & $38.99 * * *$ & $28.12 * * *$ \\
\hline
\end{tabular}

Note: Standard errors in parentheses. $* p<0.1, * * p<0.05, * * * p<0.01$.

FGLS models are run with robust standard errors.

Estimation results in Table 1 shows:

The domestic market size has a positive effect statistically significant for FDI flows into ASEAN. This result is similar to the conclusions of Normaz (2009) and Tajul (2010). Thus, the size of the internal market is an important factor in attracting FDI flows to ASEAN.

For factors of macro-economic policy: The coefficient of the exchange rate is positive statistically significant. This shows that the evaluation of currency of the host country lower than the U.S. dollar may attract FDI flows to the region, this result is similar to the search of Mamadou (2002). The coefficient of real interest rate is negative statistically significant. Obviously, the increase of the real interest rates encourage capital costs to increase, it also means that the financial risks exist, so it will limit FDI flows into the region. The coefficient of inflation is negative, as expected, but not statistically significant, this finding is also consistent with the conclusion of Ismail (2009). As expected, the coefficient of financial development is positive but not statistically significant. Clearly, in developing countries, the financial development has often a positive effect on the foreign indirect investment flows via the capital market rather than FDI inflows (Kinda, 2008).

The coefficient of the infrastructure development is positive and statistically significant. Thus, as the conclusion of Ismail (2009), the quality of infrastructure plays an important role in attracting FDI flows into ASEAN. Similarly, the coefficient of trade openness is positive and statistically significant. Studies 
Ismail (2009), Masron and Abdullah (2010) also confirmed the positive role of trade openness to attract FDI flows into the region. As expected, the coefficient of the political stability is positive and statistically significant. This means that greater political stability (meaning that the lower political risk) will strongly encourage FDI flows to the region. Similarly, the coefficient of control of corruption is positive and statistically significant at $1 \%$. Clearly, a good control of corruption helps to reduce unofficial costs, to raise quality of institution, to improve the investment environment; those are the favorable conditions to attract FDI inflows.

An important factor in choosing investment destinations for foreign investors is the low labor cost ${ }^{3}$. However, not as expected, the coefficient of the nominal labor cost is positive and statistically significant at $1 \%$. To clarify the significance of this result, we analyze an impact of labor productivity, human capital for FDI inflows. The results show that the estimated coefficient of labor productivity and human capital that reflect the labor quality are all positive and statistically significant at $1 \%$. This shows that, in determining the location of investments in the region, foreign investors are very interested by the skilled labor and labor productivity. Thus, in ASEAN, the rise of the nominal wages may be the result of improved productivity work ${ }^{4}$ and foreign investors are interested by the labor quality and labor productivity instead of the low nominal labor cost, investors can pay higher nominal wages for skilled workers who have a high productivity. To clarify this analysis, we add an interaction variable between the nominal wage and the labor productivity (INTERACTION). As expected, the coefficient of the interaction variable is positive and statistically significant at $1 \%$. This suggests a close relationship between the nominal wage rate and the high labor productivity, and this relationship helps to promote FDI flows into the region. Another aspect we see that depending on the type and nature of investments that the demand for skilled labor of FDI projects is different. Because of the characteristics of FDI projects, the demand for skilled labor may encourage investors to pass up the concerns of cheap labor cost to find labor quality. The analysis of the current structure of FDI flows into ASEAN shows that foreign investors have strong demand for the skilled labor resource ${ }^{5}$ This explains partly the positive impact of the nominal wage for FDI flows to the region.

We also use the Chow test to examine the impact of the Asian financial crisis in 1997 to the stability of the regressive coefficients of the models (see Appendix 2). These results show that the Asian financial crisis does not affect the nature of the factors of FDI flows to the region.

\section{Conclusion and policy implications}

Using panel data, this study analyzes the determinants of FDI inflows in ASEAN countries in the period 1991-2009. The results indicate that market size, trade openness, the quality of the infrastructure are macroeconomic factors that have a positive impact on FDI inflows. Associated with macroeconomic factors, exchange rate policy and the real interest rate have a significant impact on FDI inflows. However, the inflation rate and the financial development have no statistically significant impact on FDI inflows. Finally, the political risk and the institutional quality strongly influence FDI inflows in the region. One interesting finding of the study is the impact of labor factors. The nominal labor cost, the human capital, the labor productivity have a positive impact on FDI inflows in the region. This finding suggests that foreign investors are interested in the skilled labor and the labor productivity

\footnotetext{
${ }^{3}$ FDI flows into least developed countries (Schneider \& Frey, 1985) and into African countries (Wahid et al., 2009) are interested by the cheap nominal labor cost.

${ }^{4}$ In this sample, the variable nominal wage is strongly correlated with the variable labor productivity (the correlation coefficient between these two variables is 0.938 ) and with the variable skilled labor (the correlation coefficient is 0.949 ).

${ }^{5} \mathrm{FDI}$ inflows in the services sector accounts about $50 \%$ of total FDI inflows in ASEAN, is the sector that has strong demand for the high qualitative labour. In addition, approximately 50\% of total FDI flows into ASEAN came from developed countries who have a strong financial capacity and high technological (such as the European Union, the United States, Japan, Cayman Island, the Republic of Korea). It is clear that their FDI projects can have high standards and strict for the quality of labour resource to operate effectively their machines, their high technology, including the technology of management.
} 
rather than cheap nominal labor costs, accepting to pay high salaries to achieve greater labor productivity. These results have several policy implications. First, they show that even if the size of the market is one of the important factors of FDI inflows, small countries in ASEAN can also attract FDI by improving their institutions and policy environment. Political stability and a good control of corruption are the two best ways to minimize the political risks and uncertainty in the investment environment for foreign investors. In addition, they can also attract FDI that is motivated by market research through regional integration. These countries should establish close links between their domestic markets and neighboring ones. The elimination of tariff and non-tariff barriers with the neighboring countries, the development of international infrastructures (especially the system of transnational highways) are the best ways to form a single regional market. This also suggests the interest of a single transnational market in the Indochinese peninsula ${ }^{6}$, which have a unique position of ASEAN since it is not divided by the sea. The results also suggest that the backward countries of ASEAN (such as Vietnam, Laos, Cambodia, Myanmar), which attract small amounts of FDI must accelerate infrastructure development, trade liberalization, trade openness, and the progress towards regional integration in ASEAN. In addition, a weak level of the national currency against the U.S. dollar can help boost their exports, but also promote FDI inflows. Finally, it is important to note that a cheap labor is not necessary in attracting FDI flows in ASEAN countries, while the labor quality is really an important factor. In fact, the advantage of cheap labor is to attract labor-intensive FDI projects rather than technology-intensive large projects. Therefore, ASEAN countries should focus human capital development, allowing them to compete in attracting FDI, and to absorb it effectively.

\section{References}

Ali, F. A., Fiess, N., \& MacDonald, R. (2010). Do institutions matter for foreign direct investment?. Open Economies Review, 21(2), 201-219.

Asiedu, E. (2002). On the determinants of foreign direct investment to developing countries: is Africa different?. World development, 30(1), 107-119.

Asiedu, E. (2006). Foreign direct investment in Africa: The role of natural resources, market size, government policy, institutions and political instability. The World Economy, 29(1), 63-77.

Axarloglou, K. (2004). Local labor market conditions and foreign direct investment flows in the US. Atlantic Economic Journal, 32(1), 62-66.

Beck, N., \& Katz, J. N. (1995). What to do (and not to do) with time-series cross-section data. American political science review, 89(03), 634-647.

Beer, F. M., \& Cory, S. N. (1996). The locational determinants of US foreign direct investment in the European Union. Journal of Financial and strategic Decisions, 9(2), 43-53.

Blonigen, B. A., Davies, R. B., Waddell, G. R., \& Naughton, H. T. (2007). FDI in space: Spatial autoregressive relationships in foreign direct investment. European Economic Review, 51(5), 13031325.

Çevis, İ., \& Çamurdan, B. (2007). The Economic Determinants of Foreign Direct Investment in Developing Countries and Transition Economies. The Pakistan Development Review, 285-299.

Culem, C. G. (1988). The locational determinants of direct investments among industrialized countries. European Economic Review, 32(4), 885-904.

Cushman, D. O. (1987). The effects of real wages and labor productivity on foreign direct investment. Southern economic journal, 174-185.

Dunning, J. H., \& Lundan, S. M. (2008). Multinational enterprises and the global economy. Edward Elgar Publishing.

Dutta, N., \& Roy, S. (2011). Foreign direct investment, financial development and political risks. The Journal of Developing Areas, 44(2), 303-327.

Friedman, J., Fung, H. G., Gerlowski, D. A., \& Silberman, J. (1996). A Note on" State characteristics and the location of foreign direct investment within the United States.". The Review of Economics and Statistics, 78(2), 367-68.

\footnotetext{
${ }^{6}$ Including four ASEAN countries: Vietnam, Laos, Cambodia and Thailand.
} 
Froot, K. A., \& Stein, J. C. (1992). Exchange rates and foreign direct investment: an imperfect capital markets approach.

Garretsen, H., \& Peeters, J. (2009). FDI and the relevance of spatial linkages: do third-country effects matter for Dutch FDI?. Review of World Economics, 145(2), 319-338.

Greene, W. H. (2000). Econometric analysis 4th edition.

Hattari, R., Rajan, R. S., \& Thangavelu, S. (2008). Understanding Intra-ASEAN FDI flows: Trends and determinants and the role of China and India. Department of Economics, National University of Singapore, Department of Economics, Unpublished Paper.

Hayakawa, K., \& Matsuura, T. (2011). Complex vertical FDI and firm heterogeneity: Evidence from East Asia. Journal of the Japanese and International Economies, 25(3), 273-289.

Hoechle, D. (2007). Robust standard errors for panel regressions with cross-sectional dependence. Stata Journal, 7(3), 281.

Ismail, N. W. (2009). The determinant of foreign direct investment in ASEAN: a semi-gravity approach. Transition Studies Review, 16(3), 710-722.

Iwasaki, I., \& Suganuma, K. (2005). Regional distribution of foreign direct investment in Russia. PostCommunist Economies, 17(2), 153-172.

Kinda, T. (2008). Infrastructure and private capital flows in developing countries. Munich Personal RePEc Archive Paper, 19158.

Klein, M.W. and Rosengren, E. (1990) Determinants of Foreign Direct Investment in the United States, Clark University Working Paper 90 - 3.

Ledyaeva, S. (2009). Spatial econometric analysis of foreign direct investment determinants in Russian regions. The World Economy, 32(4), 643-666.

Mamadou, C. (2002). Les Investissements Directs de l'étranger et l'intégration régionale: les exemples de l'ASEAN et du MERCOSUR. Revue Tiers Monde, 169, pp 47-69.

Masron, A., \& Abdullah, H. (2010). Institutional quality as a determinant for FDI inflows: evidence from ASEAN. World Journal of Management, 2(3), 115-128.

Mengistu, A. A., \& Adhikary, B. K. (2011). Does good governance matter for FDI inflows? Evidence from Asian economies. Asia Pacific business review, 17(3), 281-299.

Mercereau, B. (2005). FDI Flows to Asia: Did the Dragon Crowd Out the Tigers? IMF Working Paper $\mathrm{WP} / 05 / 189$.

Mina, W. (2007). The location determinants of FDI in the GCC countries. Journal of Multinational Financial Management, 17(4), 336-348.

Moosa, I. A., \& Cardak, B. A. (2006). The determinants of foreign direct investment: an extreme bounds analysis. Journal of Multinational Financial Management, 16(2), 199-211.

Mottaleb, K. A., \& Kalirajan, K. (2010). Determinants of foreign direct investment in developing countries a comparative analysis. Margin: The Journal of Applied Economic Research, 4(4), 369404.

Nachum, L. (1999). World Investment Report 1998: Trends and Determinants.

Noorbakhsh, F., Paloni, A., \& Youssef, A. (2001). Human capital and FDI inflows to developing countries: New empirical evidence. World development, 29(9), 1593-1610.

Poelhekke, S., \& Van Der Ploeg, F. (2009). Foreign direct investment and urban concentrations: unbundling spatial lags . Journal of Regional Science, 49(4), 749-775.

Wahid, A. N., Sawkut, R., \& Seetanah, B. (2009). Determinants of Foreign Direct Investments (FDI): Lessons from the African Economies. Journal of Applied Business and Economics, 9(1), 70.

Wei, S. J. (2000). How taxing is corruption on international investors?. Review of economics and statistics, 82(1), 1-11.

Woodward, D. P. (1992). Locational determinants of Japanese manufacturing start-ups in the United States. Southern Economic Journal, 690-708.

Woolridge, J. M. (2002). Econometric analysis of cross section and panel data. 
Appendix 1

Data Source

\begin{tabular}{|c|c|c|}
\hline Variable & Definition & Source \\
\hline FDI & FDI inflows & UNCTAD \\
\hline MARKET & Gross Domestic Product (U.S. dollar) & World Development Indicator, 2010 \\
\hline EXCHANGE & $\begin{array}{c}\text { Exchange rate of currency of the host country } \\
\text { against the U.S. dollar }\end{array}$ & World Development Indicator, 2010 \\
\hline INTEREST & Real interest rate & World Development Indicator, 2010 \\
\hline RISK & General index of political risk & The International Country Risk Guide \\
\hline HUMAIN & Skilled labor to numbers of employees & $\begin{array}{c}\text { International Labor Organization (ILO) } \\
\text { http://laborsta.ilo.org/ }\end{array}$ \\
\hline WAGE & $\begin{array}{l}\text { Monthly average wage } \\
\text { in the manufacturing sector (U.S. dollar) }\end{array}$ & $\begin{array}{c}\text { International Labor Organization (ILO) } \\
\text { http://laborsta.ilo.org/ } \\
\text { Department Of Statistics Malaysia } \\
\text { http://www.statistics.gov.my } \\
\text { General Statistics Office of Vietnam }\end{array}$ \\
\hline PRODUCTIVITY & GDP per employee & World Development Indicator, 2010 \\
\hline CORRUPTION & Control of Corruption index & The International Country Risk Guide \\
\hline OPEN & (Imports + Exports) to GDP & World Development Indicator, 2010 \\
\hline INFLATION & Inflation, consumer prices & World Development Indicator, 2010 \\
\hline INFRASTRUCTURE & $\begin{array}{c}\text { Total numbers of phones and mobile phone } \\
\text { users (per } 100 \text { people) }\end{array}$ & World Development Indicator, 2010 \\
\hline FINANCE & $\begin{array}{l}\text { Domestic credit provided by banking sector } \\
\text { (\% of GDP) }\end{array}$ & World Development Indicator, 2010 \\
\hline
\end{tabular}

\section{Appendix 2}

Determinants of FDI inflows in ASEAN (1991-2009)

\begin{tabular}{|c|c|c|c|c|c|c|}
\hline Model & (1) & (2) & (3) & (4) & (5) & (6) \\
\hline Estimation method & $\begin{array}{l}\text { Random- } \\
\text { Effects }\end{array}$ & $\begin{array}{l}\text { Random- } \\
\text { Effects }\end{array}$ & $\begin{array}{l}\text { Random- } \\
\text { Effects }\end{array}$ & $\begin{array}{l}\text { Random- } \\
\text { Effects }\end{array}$ & $\begin{array}{l}\text { Random- } \\
\text { Effects }\end{array}$ & $\begin{array}{l}\text { Random- } \\
\text { Effects }\end{array}$ \\
\hline \multirow[t]{2}{*}{ MARKET } & $0.520 * * *$ & $0.659 * * *$ & $0.286^{* * *}$ & $0.498 * * *$ & $0.659 * * *$ & $0.480^{*}$ \\
\hline & $(0.176)$ & $(0.208)$ & $(0.103)$ & $(0.127)$ & $(0.0903)$ & $(0.267)$ \\
\hline \multirow[t]{2}{*}{ EXCHANGE } & 0.123 & 0.0789 & $0.159 * *$ & $0.116^{*}$ & $0.0557 * * *$ & \\
\hline & $(0.0766)$ & $(0.0774)$ & $(0.0764)$ & $(0.0678)$ & $(0.0194)$ & \\
\hline \multirow[t]{2}{*}{ INTEREST } & $-0.0520 * *$ & $-0.0760 * * *$ & $-0.0417 * * *$ & $-0.0476 * *$ & $-0.0361 * * *$ & \\
\hline & $(0.0204)$ & $(0.0230)$ & $(0.0121)$ & $(0.0227)$ & $(0.00940)$ & \\
\hline \multirow[t]{2}{*}{ CORRUPTION } & 0.282 & $0.403^{*}$ & 0.212 & 0.187 & & $0.348^{* * *}$ \\
\hline & $(0.232)$ & $(0.238)$ & $(0.187)$ & $(0.229)$ & & $(0.133)$ \\
\hline \multirow[t]{2}{*}{ WAGE } & $0.631 * * *$ & & & & & \\
\hline & $(0.145)$ & & & & & \\
\hline \multirow[t]{2}{*}{ HUMAIN } & & $0.0275^{* * *}$ & & & & \\
\hline & & $(0.00714)$ & & & & \\
\hline \multirow[t]{2}{*}{ PRODUCTIVITY } & & & $0.693 * * *$ & & & \\
\hline & & & $(0.130)$ & & & \\
\hline \multirow[t]{2}{*}{ WAGE*PRODUCTIVITY } & & & & $0.0430 * * *$ & & \\
\hline & & & & $(0.00671)$ & & \\
\hline \multirow[t]{2}{*}{ RISK } & & & & & $2.400^{* *}$ & \\
\hline & & & & & $(1.009)$ & \\
\hline \multirow[t]{2}{*}{ OPENNESS } & & & & & $0.00443 * * *$ & \\
\hline & & & & & $(0.00142)$ & \\
\hline \multirow[t]{2}{*}{ INFLATION } & & & & & & -0.0111 \\
\hline & & & & & & $(0.0210)$ \\
\hline \multirow[t]{2}{*}{ INFRASTRUCTURE } & & & & & & $0.274 * * *$ \\
\hline & & & & & & $(0.0844)$ \\
\hline \multirow[t]{2}{*}{ FINANCE } & & & & & & 0.00136 \\
\hline & & & & & & $(0.00441)$ \\
\hline \multirow[t]{2}{*}{ constant } & 4.239 & 3.534 & $7.730^{* *}$ & $6.546^{*}$ & -5.677 & 8.000 \\
\hline & $(4.824)$ & $(5.366)$ & $(3.185)$ & (3.763) & (3.804) & $(6.866)$ \\
\hline$N$ : Number of Observation & 100 & 94 & 104 & 92 & 106 & 99 \\
\hline \multirow{3}{*}{$\begin{array}{cc}\text { R-squared } & \text { Within } \\
& \text { Between } \\
\text { Overall }\end{array}$} & 0.40 & 0.44 & 0.39 & 0.43 & 0.38 & 0.37 \\
\hline & 0.71 & 0.72 & 0.85 & 0.80 & 0.93 & 0.75 \\
\hline & 0.56 & 0.59 & 0.62 & 0.65 & 0.65 & 0.57 \\
\hline \multirow{3}{*}{$\begin{array}{l}\text { Hausman Test } \\
\text { Ramsey Reset Test } \\
\text { Chow Test }\end{array}$} & -0.07 & 3.23 & 2.36 & 0.80 & 3.61 & 4.76 \\
\hline & 3.86 & 1.24 & 0.14 & 1.35 & 2.67 & $5.75^{*}$ \\
\hline & $(0.88)$ & $(0.49)$ & $(0.82)$ & $(0.99)$ & $(0.91)$ & 0.56 \\
\hline
\end{tabular}

